\title{
Calvinisme as Wortel van Ons Volksbestaan.
}

DIE boodskap van die Van Riebeeck-feeste aan ons volk is die van die geestelike krisis waarin die sinkretisme ons volk laat beland het; dit is die boodskap van die rooi ligteken, die gevaarsein. Daardie boodskap stel ons volk na 300 jaar voor die keuse om terug te keer tot die ou paaie of om homself te verloor en in ' $n$ ander volk onder te gaan.

Deur H. G. STOKER.

„Ons gaan met 'n vaste vertroue op 'n alsiende en genadige God wat ons altyd sal vrees en in alle nederigheid sal probeer gehoorsaam"so lui 'n uitspraak uit die manifes van Piet Retief.

„Ek is oortuig dat God Sy mense nie sal verlaat nie, al lyk dit so. Daarom onderwerp ek my aan Gods wil. Hy is die Heer, Hy het het al die harte in Sy hande en bestuur hulle na Sy wil", het S. J. P. Kruger gespreek toe hy verneem het van die vrede na die tweede Engelse oorlog.

Is dit nodig om dergelike uitsprake te gee van 'n Andries Pretorius en 'n M. T. Steyn, van 'n Christiaan de Wet en 'n Koos de la Rey, van 'n J. D. Kestell en 'n J. D. du Toit?

Uit dergelike Godsvertroue spreek die gees van die Calvinis. „Dié Godsvertroue staan vas, of dit golfies is wat saggies teen die rots kabbel, en of dit skuimende branders is wat daarteen slaan. Hierdie geloofsvertroue gee hom die versekerdheid dat alles uit God is, deur Hom en to Hom. Hy spreek dit uit in geloofstaal: ,God is 'n toevlug en sterkte ... Daarom sal ons nie vrees nie, al skud die aarde en al wankel die berge weg in die hart van die see'. Sy oor hoor die stem uit die ewigheid: ,Ek sal jou nooit begewe en jou nooit verlaat nie'." (J. D. Kestell in Koers in die Krisis, I.)

Vergelyk met hierdie taal die gebed van Jan van Riebeeck, wat elders in hicrdie tydskrif afgedruk staan.

Vergelyk hiermee uitsprake van die Sinode van Dordt, van ons Nederlandse Geloofsbelydenis (o.a. art. XIII), van Hugenote (o.a. van Caspar de Coligny) en van Calvyn. 
Vergelyk hiermee die openbaring van God Self in Sy Woord.

Nie verniet eindig ons met hierdie revue by die Heilige Skrif nie. Want al die betrokke uitsprake grond hulle op Gods Woord. Die geloof in die Bybel as die onfeilbare Woord van God Self, Skepper van hemel en aarde, van God Drie-enig, en die geloofsoortuiging dat waar God spreek, alle menslike teëspraak sal ophou-dit is kenmerkend van die Caivinisme.

As eerste fundamentele beginsel leer die Heilige Skrif ons: „Uit Hom, deur Hom en tot Hom is alle dinge. Syne is die heerlikheid in der ewigheid. Amen" (Rom. 11:36). Hierdie radikaal teosentriese waarheid lê aán die Calvinistiese kennisse Gods, aan die Calvinistiese lewens- en wêreldbeskouing, aan die Calvinistiese lewenshouding en lewenstyl ten grondslag.

Volgens die Heilige Skrif en daarom vir die Calvinis is hierdie grondbeginsel universeel: dit betref alle dinge. Kenmerkend is dan ook dat die Calvinis universeel uit hierdie grondwaarheid lewe en die universaliteit van hierdie beginsel konsekwent bely. Hy weet dat God alles bestuur en alles beskik, dat alles in Sy hand is en dat die mens in alles wat hy doen en laat, voor Gods aangesig staan en vir alles wat hy doen en laat, aan God verantwoordelik is.

Hierdie grondwaarheid gee egter ook die eenheid aan sy geloof en aan sy lewens- en wêreldbeskouing, aan sy lewenshouding en lewenstyl, aan sy hele lewenservaring, ja, aan alles wat bestaan, en aan alle verskeidenheid van en in Gods geskape heelal.

Met hierdie fundamentele beginsel is ' $n$ tweede gegee wat die Calvinis ook in alle konsekwensie aanvaar en bely, nl. dat God absoluut soewerein is oor alles wat Hy geskape het, en ook oor die mens in al sy doen en late, dat Hy Wetgewer is vir alles wat bestaan, en Sy ordinansies vir alles gestel het en dat die mens in al sy doen en late onder die wil en die wet van God staan, Hom in alles gehoorsaam moet wees.

Implisiet is in beide beginsels die volgende gestel, nl. „,de waarheid dat de wereld Gods wereld is.* Ze ontstond door Hem, maar ze bestaat ook voor Hem. De redding van de enkele mensch is voor dien mensch gewichtig, maar het Calvinisme plaatst dat niet in het centrum van zijn beschouwing. Dit centrum ligt elders, $\mathrm{nl}$. in de redding van de gansche wereld, omdat deze wereld Gods wereld is. Daarom moet elke levensuiting: Kerk, Staat, Maatschappij, Wetenschap, Kunst, gezien worden als in constante relatie tot den Almachtige te staan. Daarom kan de

* Swart druk deur ons. 
Calvinist niet blijven staan bij de Kerk alleen; daarom moet ook het natuurlijk leven gezien worden te staan onder de heerschappij van de fundamenteele gedachte" (Dr. H. Colijn in Koers in die Krisis, l.)

Hierdie wêreld, die hele skepping, ook die mens met sy godsdiens en kultuur, d.w.s. sy sedelike optrede, met sy regsvorming, met sy kunsskepping, met sy bou van taal, van wetenskap en van ekonomie en handel, ja, met sy hele geskiedenis, ook met sy kerk, met sy staat en politiek, met sy volksbou, gesinsvorming en maatskappyvorming, met sy hele lewe, ook sy natuurlike lewe-dit alles behoort aan God en staan in Sy diens en is bestem tot Sy eer en verheerliking. En Christus is nie net Verlosser en Saligmaker van die in sonde gevalle mens nie maar ook Herskepper van die ganse heelal, Koning op alle terreine van menslike bedrywigheid, en nie net van Sy kerk nie. En Gods Woord is nie net bedoel om die mens op die kruis van Christus te wys nie maar belig die hele werklikheid en is ,'n lamp vir my voet en 'n lig vir my pad" (Ps. 119: 105).

Hierdie waarheid dat alles aan God behoort en aan Sy Christus, en ons alles, ook ons hele lewe, ,in U lig" moet sien en daarvolgens moet wandel, bely en handhaaf die Calvinis in alle konsekwensie. Daardeur breek hy radikaal met die dualisme van die Rooms-Katolisisme, nl. die leer van die twee terreine, en wel die van die genade en die van die natuur. Maar daarmee verskil hy ook van alle parsiële Christendom (soos die Lutheranisme, Metodisme, Barthianisme), wat die Christendom beperk tot kerk en godsdiens. En daarmee breek hy ook met alle Christendom (soos die Liberalistiese, die Kritisistiese en die Dialektiese) wat nie die Bybel as geheel as Gods onfeilbaar Woord en as ' $n$ lig op alle lewensterreine aanvaar nie. Dit is dan ook alleen die Calvinisme wat as 'n totalitêre Christendom in alle konsekwensie die noodsaaklikheid insien van 'n Christelike wetenskap, 'n Christelike politiek, 'n Christelike kuns, 'n Christelike ekonomie, ja, van die christianisering van die hele kultuur en nie net die noodsaaklikheid van 'n Christelike godsdiens stel nie; en wat verder die eis stel van 'n Christelike verlowing, 'n Christelike huwelik, 'n Christelike gesin, 'n Christelike volk, 'n Christelike skool, 'n Christelike vakvereniging, ja, van die christianisering van die hele samelewing en hom nie net beywer vir en in 'n Christelike kerk nie.

Dit is wel waar dat die insig in en die verwerkliking van 'n christianisering van die hele kultuur en van die samelewing eers in latere en onlangse tye algaandeweg meer eksplisiet sy beslag gekry het; maar dit is tog 'n Skriftuurlike en meteen 'n werklikheidseis wat Calvyn reeds in beginsel gevind en ten dele reeds uitgewerk het (vgl. sy uitbouing van 'n staatsteorie, sy bydrae tot oplossing van ekonomiese vraagstukke en so meer), en dis 'n beginsel wat ook in die ontwikkeling van ons volkslewe 
en volkskultuur deurgewerk het en tot die bevordering waarvan ons volk ook sy besondere bydrae gelewer het (soos o.a. grotendeels spreek. uit sy rassebeleid).

Nieteenstaande maar juis op grond van sy totalitêre christianisering van die hele lewe eerbiedig die Calvinis die beginsel van verskeidenheid. God het 'n verskeidenheid in Sy skepping gelê en laat ontwikkel, 'n verskeidenheid wat saamhang, maar 'n verskeidenheid wat sy uiteindelike eenheid in Sy veelkleurige wysheid (polupoikilê sophia tou Theou) en in Sy skeppings- en bestieringswil vind. Die Calvinis soek geen skeiding van lewensterreine en van samelewingskringe nie, geen skeiding van kerk en volk, kerk en staat, kerk en maatskappy, kerk en skool, ens., en van godsdiens en wetenskap, godsdiens en politiek, godsdiens en ekonomie en van godsdiens en kuns, ens. - soos bv. die Liberalis doen-nie, maar 'n verband, 'n samehang en samewerking tussen al die terreine en al die kringe. Aan die ander kant soek hy geen gelykmaking, geen gelykskakeling, geen nivellering van verskille en geen uitwissing van grense tussen kerk en staat, kerk en volk, kerk en maatskappy, kerk en skool, ens., en tussen godsdiens en wetenskap, godsdiens en kuns, godsdiens en politiek en godsdiens en ekonomie, ens.-soos die Totalitaris, bv. die Nasionaal-sosialis doen-nie, maar 'n skerpe onderskeiding tussen al hierdie terreine en al hierdie kringe. Want elke kring en elke terrein het sy besondere eie-aard, staan onder besondere ordinansies van God, het sy besondere bestemming en is in sy besonderheid soewerein in eie kring.

Die konsekwente erkenning van 'n samehangende maar onherleibare en nie-gelykmaakbare verskeidenheid is ' $n$ eg-Skriftuurlike beginsel asook ' $n$ beginsel in Gods skepping geleë, 'n beginsel waaraan Calvyn reeds op verskillende wyses eksplisiet uitdrukking verleen het, o.a. in die bepaling van die verhouding van kerk en staat, 'n beginsel wat juis ook in die rassebeleid van die Afrikaner so duidelik tot uitdrukking kom.

Dis hierdie verskeidenheidsbeginsel wat die Afrikaner so sterk bewus gemaak het van sy eie identíeit as volk, soos o.a. blyk uit sy rassebeleid, uit sy stryd teen verengelsing, uit die Groot Trek, uit die Engelse oorloë, uit die stryd vir 'n eie taal, 'n eie kultuur, 'n eie skool, 'n eie politieke organisasie, 'n eie ekonomiese ontwikkeling en so meer. Maar hierdie identiteitsbewussyn stel sy identiteit voor Gods aangesig as 'n van God gewilde identiteit; m.a.w. sy identiteitsbewussyn word gedra en verdiep deur sy roepingsbesef. Hy glo dat God hom hier as volk geplant het, sy besondere aard en sy eie identiteit as ' $n$ bestemming geskenk het om aan die suidelike deel van ons Afrikaanse kontinent, ja, selfs vir die hele kontinent ' $n$ besondere roeping te vervul, ' $n$ bepaalde van God opgelegde taak te verwesenlik. 
„'n Roeping . . . . Let op hierdie woord . . . . Die woord ,roeping' het vir ons 'n heilige klank en 'n heiligende krag. Ondat dit onderstel stipte gehoorsaamheid aan die stem van die Here! (1 Sam. 15: 22). Dieselfde God wat van ewigheid tot ewigheid, deur sy uitverkiesing, oor ons lewe beskik, bepaal ook ons bestaan op aarde. Sodra daarom die sielelewe van die gelowige ontwikkel, sodat hy kan dink en wil, roep God hom tot sy besondere lewenstaak en gee hom daartoe sy aanstelling. Vat dit streng op. Hierdie waarheid laat ons met bewende erns verskyn voor God, ons Skepper en ons Regter tewens. Eenmaal geroep-en ons behoort vir altyd, hetsy dat ons lewe of sterwe aan die Here (Rom. 14: 8). Alle eiewilligheid is dan op ' $n$ end. . . . Die woord, roeping' het dus 'n skerpe klank. Maar daarom vrees ons nie daarvoor nie. Inteendeel, dit is vir ons die skerpe klank van krygsmusiek; . . . die krygsmusiek van die roeping van God dien om ons uit ons ywerloosheid op te skrik en ons te besiel met 'n blye gees, sodat ons met moed verder kan gaan" (J. D. du Toit in Koers in die Krisis, l.) Deur ons in ons besondere omstandighede en met ons besondere identiteit te roep, stel God ons ons taak en staan ons in Sy diens, juis ook as Afrikanervolk.

Uit sy hele geskiedenis en sy stryd op die onderskeie lewensterreine blyk duidelik dat en hoe die Afrikaner roepingsbewus was. Dit is te bekend om daarvoor nog uitsprake van sy leiers uit die verlede aan te haal, uitsprake wat die volk juis tot roepingsverwesenliking aangemoedig en aangespoor het.

Maar nog meer; vir hom was-eg-Calvinisties, m.a.w. suiwer Skriftuurlik-roeping en vryheid innig en wesentlik verbind. Die Afrikaner se vryheidsbesef het in sy roepingsbesef gewortel; hy het juis sy vryheid opgevat as 'n van God gegewe kleinood wat hy as persoon en as volk moet bewaar en handhaaf. Sy vryheidsin was nie die van die Franse Revolusie, met sy volksoewereiniteit en sy, geen God en geen meester bo ons nie', nie die van die Liberalis, wat individuele selfbestemming as die laaste grond van sy vryheid sien nie, en ook nie die van die uitheemse Nasionaal-Sosialis, wat menslike vryheid slegs in die volkse selfbestemming fundeer nie; sy vryheidsin was Gode-verankerd; vryheid was vir hom die aan God verantwoordelike verwesenliking van 'n individuele en sosiale van God gegewe menslike bestemming, 'n bestemming waarvoor God aan hom as individu en as sosiale wese, veral ook as volk, sy besondere identiteit, sy besondere omstandighede en geleenthede en daarvolgens sy besondere taak gee. Dit is hierdie vryheidsin van die Afrikaner op die verskillende lewensterreine waarvan sy geskiedenis, veral in sy groot momente, so kragtig getuig. Dis 'n vryheidsin wat gekenmerk word deur 'n verantwoordelikheidsin aan die Gewer van sy 
vryheid. Uit hierdie vryheidsin het sy moed en heldedade voortgespruit. Dis 'n vryheidsin wat ons histories kan terugvoer tot die van Geus en Hugenoot, tot die van die Calvinistiese Reformatore soos dit wortel in die volle waarheid van Gods Woord.

Vir die Calvinis en so ook vir die Afrikaner was daar altyd 'n intieme verband tussen identiteit, roeping en vryheid en tussen sy identiteitsbewussyn, sy roepingsbesef en sy vryheidsin-en dit op alle lewensterreine.

Moet ek nou uitwei oor sy paring van 'n nugtere werklikheidsin aan 'n beginselidealisme of oor sy besondere eerbiediging van gesag in menslike verhoudings, soos dit so sterk uitgekom het bv. in sy sin vir die patriargale gesag in gesinsverhoudings of oor ander fundamentele bepalings van sy Godsgeloof, van sy lewens- en wêreldbeskouing en van sy lewenshouding en lewenstyl?

Wie hom in bostaande lyne verdiep en daardie lyne in ons volksgeskiedenis ontwaar, sal toestem dat met reg gespreek kan word van die Calvinisme as wortel van ons volksbestaan. Ja, 'n volk het wel 'n fisiekbiotiese kant, nl. afstammingsverwantskap, maar dit het ook 'n geestelikkulturele kant, 'n geestelike erfenis deur tradisie van geslag tot geslag oorgedra en deur progressie uitgebou. En dit is juis wat sy geestelike erfenis betref dat ons kan spreek van die Calvinisme as wortel van ons volksbestaan.

Ons kan die Calvinisme as wortel van ons volksbestaan eerstens horisontaal,d.w.s. in historiese lyn, sien. Die oorspronklike koloniste, die latere Hugenote en ander immigrante, waaruit ons volk ontstaan en geword het, het met 'n Calvinistiese lewenshouding en 'n Calvinistiese Godsgeloof en lewens- en wêreldbeskouing, m.a.w. met 'n Calvinistiese geestesgoed, hierheen gekom. Ons volk is met hierdie Calvinistiese geestelike erfenis gebore en het hiermee grootgeword.

In die tweede plek kan ons die Calvinisme as wortel van ons volksbestaan in vertikale lyn sien, d.w.s. in die verhouding waarin ons volk gedurende sy geskiedenis hom bewustelik tot God gestel het. Die grond hiervan is veral dat ons volk in die mate wat hy in die binneland ingetrek en later na die Noorde getrek het, in 'n betreklike isolement van die buitewêreld gelewe het, teenoor gevare en bedreiginge van die nog woeste natuur en naturellestamme te staan gekom het en as geestelike besit juis en veral gehad het die Statebybel, die Psalmboek met sy Nederlandse geloofsbelydenis en werke van Gereformeerde outeurs soos die van A Brakel en ander. Juis in die gegewe omstandighede met al hul gevare waarteenoor hy in sy betreklike isolement te staan gekom het, en met sy geestesbesit en geesteshouding het hy hom telkens opnuut 
onmiddellik tot God gerig, en dit het die vertikale worteling van ons volksbestaan in die Calvinisme bevestig.

Hiermee word nie betoog dat elkeen wat hom hier in ons sonnige Suid-Afrika kom vestig het en tot ons volkswording bygedra het en elke volksgenoot tydens die geskiedenis van ons volk as Calvinis bestempel moet word nie. Die geskiedenis getuig wel anders. Ook ons volkslewe ken soos die van ander volke meer as een geestesrigting. Maar-en dit is van belang-die Calvinistiese rigting het sowel in die oorsprong as in die geskiedenis van ons volk die sentrale en die oorwegende, m.a.w. die geestelike kern van ons volksbestaan gevorm. Vanaf sy oorsprong en in sy geskiedenis was ons volksideologie wesentlik Calvinisties.

Daaruit moet ook verklaar word dat gedurende ons volksbestaan (tot onlangs) vreemde ideologieë wat van buite af ingebring is, hulle nie in hul radikale aard hier kon handhaaf en geen radikale invloed op ons volksbestaan uitgeoefen het nie maar Calvinisties getemper en omgevorm is. Seker, die ideë van die Franse Rewolusie het hier posgevat, maar nie in hul radikale vorm van "geen God en geen meester oor ons" nie, maar het grotendeels aangepas aan die bestaande Calvinistiese geestesrigting. Dieselfde kan gesẽ word van ander rigtings, soos die rasionalisme, die liberalisme, die metodisme en selfs die nasionaal-sosialisme.

Ek wens dat 'n Calvinistiese historikus sou opstaan wat 'n ideologiese geskiedenis van ons volk op alle (kerklike, staatse, volkse, maatskaplike, kulturele en ander) terreine sou beskrywe. Ons het wel reeds 'n breed en intensief uitgewerkte kerkgeskiedenis, politieke en ekonomiese geskiedenis, waarin vanselfsprekend die ideologiese momente van ons volksgeskiedenis aangeraak word, maar nog nie 'n breed en intensief uitgewerkte geskiedenis wat die ideologie van ons volk tot sentrale tema het en wat nagaan wat die rol en invloed van die Calvinisme en sy verhouding tot, bepaling deur en inwerking op ander ideologieë in ons volkslewe was nie.. So 'n geskiedskrywing sal m.i. bevestig wat hierbo gestel is, nl. dat die Calvinistiese waarheid, die Calvinistiese beginsels, die Calvinistiese Godsgeloof, lewens- en wêreldbeskouing, die Calvinistiese lewenshouding en lewenstyl, m.a.w. die Calvinisme as omvattende ideologie en krag, die eintlike geestelike wortel van ons volksbestaan is.

Die Calvinisme is in sy grondbeginsels en in sy grondhouding universeel en orals dieselfde. Dit is egter in sy historiese verwerkliking gevarieerd en vorm en ontwikkel in elke volk met sy besondere aard en omstandighede ' $n$ besondere tipe. „Die Afrikaanse Calvinisme is elementêr, minder filosofies deurdink en uitgewerk as in ouer lande; dit is egter ook meer spontaan en prakties in sy toepassing op die volkslewe, wat trouens in 'n jong land soepel is en nog nie gestereotipeer nie. Hy 
het voor 'n kragproef te staan gekom en dit glansryk deurstaan, nl. om sy houding te bepaal teenoor die naturellevraagstuk. Spontaan het die eenvoudige Boer-Calvinis die patriargale houding gekies en vir geslagte volgehou. Dit het van beslissende waarde geblyk vir die sedelike en nasionale bestaan van die Afrikanervolk. Dat 'n handvol witmense hulle rein gehou het, met weinig uitsonderings van menslike swakheid in 'n swart see van barbaredom, is 'n skitterende vindikasie van die Calvinisme as 'n kolonisasie-prinsipe. Vergelyking van Suid-Afrika met Suid-Amerika is in dié opsig baie leersaam! . . Dit kom ons voor dat hy aan die Nederlandse Calvinisme sy lewenserns, sy leer- en kerkvastheid en sy nugterheid te danke het; aan die Franse Calvinisme sy kinderlike en diepe vroomheid; aan die Engelse, al is dit indirek, sy onmiskenbare Puriteinse inslag. Sy spontaan ontwikkelde en sy oorgeërfde goeie eienskappe het hy onder Gods seën hard nodig om die groot vyande te weerstaan wat hom belaag: metodisme, modernisme, isolasie, gebrek aan deurgevoerde organisasie en swart en wit heidendom." (G. Besselaar in Koers in die Krisis, I.) Juis ook 'n dergelike tipering van die besondere aard van die Afrikaanse Calvinisme moet in die ideologiese geskiedbeskrywing van ons volk tot sy reg kom. En is dit nog nodig om in hierdie verband te wys op die Christelik-republikeinse ideologie, die republikeinse ideale en republikeinse sin en die besondere republiekvorming van die Afrikaanse Calvinis?

Maar as ons vandag op ons volk let, dan is dit opvallend dat veral in die laaste 50 jaar ons volk oorstroom is met vreemde ideologieë en dat op verskillende terreine geestelike verwarring intree. En desnieteenstaande ontbreek by ons volk oorwegend die bewuste antitese. In die buiteland (bv. Europese en Noord-Amerikaanse lande) bestaan die bewuste antitese van Calvinis en anti-Calvinis, van Christen en anti-Christen; daar kom 'n ateïs vir sy oortuigings uit en vorm 'n ateïste-bond; daar val die materialis die Christendom aan en vorm 'n bond van materialiste; daar bestry die nie-Christelike sosialisme die Christendom; daar beveg die konsekwente liberalis en humanis sowel as die konsekwente positivis en evolusionis die Christen; daar kry 'n Nietzsche, 'n Häckel, 'n Freud en 'n Sartre sy aanhang; en so kan ons aangaan. Maar hier by ons wil in die algemeen algar nog as Christene beskou word, voel byna elkeen dit as ' $n$ oneer aan om as 'n ongelowige of nie-Christen bestempel te word, verkies byna elkeen nog dat sy kinders gedoop sal word en dat hy 'n kerklike begrafnis sal kry-en dit juis ook by tal van origens kerklosse en kerklose volksgenote wat die Calvinisme, ja, selfs die Christendom in ruimer sin, vaarwel gesê het en 'n vreemde ideologie van harte aanvaar. 
Waarom ontstaan hier by ons vandag geen radikale antitese nie, en waarom wil so te sê algar nog vir Christene deurgaan? Is dit nie die gevolg van die kragtige invloed van ons Calvinistiese erfenis, die gevolg daarvan dat die Calvinisme die geestelike wortel van ons volksbestaan is nie? Het ons hier nie te doen met die invloed van ons Afrikaanse Calvinisme op hulle wat die Calvinistiese pad van Suid-Afrika verlaat het nie? Sou hier by ons die antitese (soos in die geval van ander volke) nie ontstaan het as die Calvinisme nie die wesentlike en sentrale krag in ons volkslewe gewees het nie en daardeur selfs hulle wat die geloof van die vaders vaarwel gesê het, nie so beïnvloed het dat hulle nog as Christene beskou wil word nie? Hier werk-eienaardig genoeg-die invloed van die Calvinisme deur tot sy eie nadeel. Want in die huidige verwarring kan die Calvinisme slegs deur die antitese suiwer bewaar word en suiwer van invloed bly.

Maar is die Calvinisme nog wortel van ons volksbestaan? „Die grondbeginsels van Calvyn was bekend in ons land; . . . hulle behoort nog bekend te wees, maar dit is veelsins nie die geval nie. Die lyne van die Calvinisme, wat duidelik in ons volkslewe te sien was, is verdof en vervaag" (J. D. du Toit in Koers in die Krisis I). Die oorstroming van ons volkslewe deur vreemde ideologieë was skynbaar vir die invloed van die Calvinisme te magtig.

Want wat het gebeur? Deur sy betreklike isolement van die buiteland en van die buitelandse invloede asook deur sy jeugdigheid en soepelheid en deur die gebrek aan kennis en aan kulturele vorming soos deur die omstandighede bepaal, het ons volk nie die nodige geestelike wapens gehad teenoor die vreemde maar hoër ontwikkelde en ouer kulture wat hulle hier kom vestig het nie-veral sinds die opheffing van die betreklike isolement van ons volk sedert die einde van die vorige eeu. Die leiers van ons volk op die verskillende lewensterreine het bowedien in groot getalle na die buiteland gegaan om hulle vir hul taak hier te lande verder te bekwaam en het aan die voete van vreemde leermeesters gaan sit en vreemde leringe en oortuigings saam teruggebring. Immigrante van ander volke en ander rigtings het hulle in ons midde kom vestig en ons vreemde gewoontes en vreemde lewenstyle geleer.

En onder hierdie stortvloed van vreemde invloede het ons volk voortgegaan om sy eie uit te bou, sy eie taal, sy eie letterkunde, sy eie kuns, sy eie politiek, sy eie ekonomie, sy eie skool, ensovoorts. Maar hierdie uitbou het algaandeweg meer en meer in die teken van 'n sinkretisme te staan gekom.

Sinkretisme is in enger sin die vereniging van die Christelike met 'n heidense godsdiens, maar in (die hier gebruikte) ruimer sin die ver- 
eniging van geloofsinhoude of van stelsels of van lewens- en wêreldbeskouings of van lewenshoudings, lewenstyle en lewensgewoontes wat op botsende grondslae, op botsende fondamente of op botsende grondbeginsels rus. Kon die Calvinisme in ons volksgeskiedenis voorheen op vreemde ideologieë temperend en omvormend ingewerk het, vandag het die vreemde ideologieë so aan krag en invloed gewen dat hulle hulself in ons volkslewe en teenoor die Calvinisme kan handhaaf. En juis omdat die Calvinisme wortel van ons volksbestaan was en nog grotendeels is, ontstaan in ons volkslewe die sinkretisnie van Calvinisme en modernisme en van Christendom en moderne heidendom asook van gereformeerde en nie-gereformeerde religie. Ons volk wil op die betrokke onderskeie terreine en in die betrokke onderskeie kringe sy Calvinisme verenig o.a. met modernisme, humanisme, liberalisme, positivisme, scientisme, evolusionisme, materialisme, pragmałisme, nasionaal-sosialisme, ekonomisme, metodisme, irrasionalisme, eksistensialisme en dialektisisme. Hy wil Calvinis én tegelyk iets anders wees. Die enigste rigting waarteen ons volk hom vierkant verset en waarmee dit (afgesien van enkele uitsonderlike gevalle) geen sinkretisme aangaan nie, is blykbaar die kommunisme, wat in sy uitgesproke anti-Christelike en anti-godsdienstige karakter en op grond van sy gevaar vir ons naturellebevolking moeilik met ons volk se Calvinisme verenigbaar is. Maar afgesien hiervan: sinkretisties is ons huweliks- en gesinslewe; sinkretisties ons skoolwese; sinkretisties ons maatskaplike lewe; sinkretisties is ons pers (met sy onverkwiklike sensasionalisme); sinkretisties ons politieke organisasies en ons volksbewegings en volksorganisasies; sinkretisties is ons wetenskaplike denke; sinkretisties ons letterkunde; sinkretisties is ons sedelike lewe; sinkretisties sou selfs ons godsdienstige en kerklike lewe genoem kon word weens die vereniging van die gereformeerde godsdiens en belydenis met die metodisme en met die dialektiese teologie.

Dat die sinkretisme bevorder word deur die ooorheersende invloed van die tegniek, deur die wêreldkontakte wat o.a. die radio en die rolfilmwese bring, cn deur die huidige wêreldwye vervlegting van ons belange met die van ander volke-dit wil ek net noem.

Die gebrek aan bewuste antitese in ons volkslewe is maar die keersy van die sinkretisme. So sinkretisties as dit hier by ons toegaan, gaan dit by ander volke nie toe nie. Sinkretisme by ons is 'n defaitistiese handeling waarmee die Calvinisme as wortel van ons volksbestaan hom teenoor die vir hom te invloedryke vreemde ideologieë nog trag te handhaaf; en dis 'n teken van swakheid.

„Defaitisties"-want sinkretisme beteken ontworteling van die Calvinisme as geestelike grondslag van ons volksbestaan. Die vreemde 
ideologieë in ons sinkretisme is soos die Trojaanse perd wat binne in die geestelike vesting van ons volk indring en dit van binne af verower. Vir die Calvinisme as wortel van ons volksbestaan is hierdie Trojaanse perd die grootste bedreiging, die gevaarlikste vyand. Ons het hier met 'n vyand te doen wat geen bewuste antitese wil laat ontstaan nie en gevolglik moeilik as vyand aangegryp kan word. Deur die sinkretisme word die Calvinisme al meer uit die sentrale en kernposisie in ons volkslewe verdring en al meer tot die uitwendige skil van ons volksbestaan uitgestoot, sodat die Christelike karakter van ons volk al meer slegs 'n uitwendige vernis word.

'n Merkwaardige byverskynsel van die sinkretisme by ons is wat ' mens „separatisme" kan noem, nl. die skeiding van die kerk aan die een kant en die ander lewenskringe aan die ander kant en ook die skeiding van die godsdiens aan die een kant en die onderskeie kultuurterreine aan die ander kant; m.a.w. die beperking van die Christelike lewe en Christelike beginsels tot kerk en godsdiens en die oorgawe van die ander kringe en terreine aan vreemde ideologieë. Hiermee word die grondbeginsel van die Calvinisme: ,uit God, deur God en tot God alle dinge”, prysgegee en daarmee ook al die ander Calvinistiese beginsels wat in hierdie beginsel wortel. En dis merkwaardig genoeg dat in hierdie separatisme die metodisme en die dialektiese teologie bondgenote is van die liberalisme, positivisme en scientisme.

Is dit nog nodig om aan te toon hoe die sinkretisme die opvallend opportunistiese gees van ons volk in die onderskeie kringe en op die onderskeie terreine bepaal? Nog meer, die sinkretisme ondermyn ons volk se identiteitsbewussyn, sy roepingsbesef en sy vryheidsin. Dit word verder bevorder o.a. deur die talryke huwelike van Afrikaners met Engelse en deur die stuksgewyse aanvaarding van 'n nuwe vryheidsideologie binne die Britse statebond en die toenemende prysgawe van ons Calvinisties-republikeinse ideale.

Deur die sinkretistiese ontworteling van die Calvinisme as wortel van ons volksbestaan is ons volk besig om in sy wese ' $n$ ander volk te word.

Let maar op ons monumentdae en hoe by elke volgende monumentdag die duidelike klanke van ons Calvinisme al minder hoorbaar word. Vergelyk in hierdie opsig die gees by die onthulling van die Vrouemonument te Bloemfontein, die gees by ons Ossewafeeste en by die hoeksteenlegging van ons Voortrekkermonument, die gees by die Rapportryersfeeste en by die inwyding van ons Voortrekkermonument en die gees by ons Poskoetsfeeste en by die feeste rondom die Van Riebeeckmonument. 
Die Van Riebeeck-feeste mag veral staan in die teken van ekonomiese en industriële vooruitgang, en ons kan hier sowel as op ander terreine van ons volkskultuur' $n$ vooruitgang bespeur waarvoor ons dankbaar kan wees; maar beskou in die lig van ons volksverlede en in die lig van die Calvinisme as wortel van ons volksbestaan, staan die feeste in die teken van 'n agteruitgang. Die boodskap van hierdie feeste aan ons volk is daarom die van die geestelike krisis waarin die sinkretisme ons volk laat beland het; dit is die boodskap van die rooi ligteken, die gevaarsein. Daardie boodskap stel ons volk na 300 jaar voor die keuse om terug te keer tot die ou paaie of om homself te verloor en in 'n ander volk onder te gaan.

Nieteenstaande hierdie agteruitgang glo ek nog dat daar 'n kern van ons volk is wat aan sy verlede ten volle trou bly en in die regte rigting voortbou, glo ek dat daar'n tyd sal kom waarin God ons volk sal wakkerskud tot 'n stryd wat die so nodige antitese sal skep en die toegedekte antitese, die dubbelslagtige en dubbelhartige karakter van die sinkretisme, sal ontbloot en daardeur vernietig, 'n stryd wat noodwendig op kerklik en godsdienstig terrein sal moet begin omdat die Calvinisme die geestelike wortel van ons volksbestaan is. Ek glo dit omdat die taak wat God aan ons volk hier in Suid-Afrika en ten bate van die hele Afrika gestel het, nog lank nie afgehandel is nie, 'n taak waarin die stryd tussen Oos en Wes 'n sentrale rol gaan speel. Dat God ons volk roep, blyk duidelik uit die roeping van ons volk in die huidige wêreldverwarring.

Daarom kan ons wat die gevaarsein van die sinkretisme onderken, vandag nog met S. J. P. Kruger sê: „Ek is oortuig dat God Sy mense nie sal verlaat nie, al lyk dit so. Daarom onderwerp ek my aan Gods wil. Ek weet dat Hy die verdrukte volk nie ten onder sal laat gaan nie. $\mathrm{Hy}$ is die Heer, Hy het al die harte in Sy hande en bestuur hulle na Sy wil."

En daarom kan ons ook saam met Piet Retief uitroep: „Ons gaan met 'n vaste vertroue op 'n alsiende en genadige God wat ons altyd sal vrees en in alle nederigheid sal probeer gehoorsaam." 